Rezek, José Francisco. A independência do Poder Judiciá irio. In: Revista da Associação dos Magistrados Brasileiros, Brasília. p.89. 1990

Rodrigues, Leda Boechat. Direito e política. Os direitos 1977.

Roenick, Henrique Osvaldo Poeta. Da necessidade de uma interpretasáa crítica do Direito. Ajuris, Porto Alegre, v.44, p.153-165, nov. 1989.

Ruivo, Fernando. Aparelbo judicial, Estado e legitimasăa. In: Direito e Justiça. A função social do Judiciário (org. José Eduardo Faria). São Paulo: Ática 1989.

Santos, Moacir Amaral. Primeiras linhas de Direito Processual Civil. v.1. São Paulo: Saraiva, 1984.

Silva, Clóvis Veríssimo do Couto e $A$ obrigação como processo. José Bushatsky, Editor.São Paulo. 1976.

Silva, Ovídio A.Baptista. Curso de processo civil. v.I Porto Aleg:re: Sérgio Fabris, 1987.

- Democracia moderna e processo civil. In: Participação e processo. (org. Ada Pellegrini Grinover et al.) São Paulo: Editora Revista dos Tribunais, 1988,p.98-113.

Sousa, José Geraldo de Jr. A crise do golfo: a deriva do direito. In: Revista de direito alternativo. v. 11992 p. 175-183. Ed. Acadêmica. São Paulo.

Tucci, José Rogério Cruz e. A motivasão da senteņ̧a no processo civil. São Paulo: Saraiva. 1987.

Valadão, Haroldo.Justiça social e interpretą̧ão. In: Revista dos Tribunais v. 564.1982.

Watanabe, Kazuo. Acesso d justica e sociedade moderna nover et al.) São Paulo.: Editora Revista dos Tribunais, 1988.
Reale, Miguel. Teoria tridimensional do (situasăo atual). São Paulo: Saraiva, 1986. bumanos no Brasil. Coleção Ajuris. Porto Alegre: In: Participação e processo. (org. Ada Pellegrini Gri-

\section{A noção de sistema no direito privado: unidade ou pluralidade}

Dissertação apresentada no Curso de Pós-Graduação em Direito da Universidade Federal do Rio Grande do Sul, como requisito parcial à obtenção do grau de Mestre. Professor Orientador: Dr. Clóvis Veríssimo do Couto e Silva

\section{Carlos Eduardo López Rodriguez}

Professor Adjunto em Direito Comercial da Universidade

da República Oriental do Uruguai e Mestrando em Direito da UFRGS.

$$
\begin{aligned}
& \text {... I suspect that in but few of you bas this } \\
& \text { problem occasioned sleepless nights, and I } \\
& \text { should not be astonished if some of you told } \\
& \text { me it had never vexed you. I myself have come, } \\
& \text { by long brooding over it, to consider it the } \\
& \text { most central of all philosophic problems, cen- } \\
& \text { tral because so pregnant ... } \\
& \text { William James, Pragmatism, The one and } \\
& \text { the many. }
\end{aligned}
$$

SUMÁRIO. Introdução. I. O Direito Privado como Sistema Ãnico. A. A Configuração Teórica da Noção de Sistema Ãnico. 1. A Concepção Jusracionalista. 2. A Concepção Positivista. 3. O Idealismo Alemão e suas Vertentes Jurídicas. B. A Consagração da Noção de Sistema Ãnico no Direito Positivo. 1. As Codificações Jusracionalistas. 2. O Código Civil Alemão.II. O Direito Privado como Pluralidade de Sistemas. A. A Refutação Teórica da Noção de Sistema Ānico. 1. O Movimento do Direito Livre. 2. A Jurisprudência de Interesses. 3. As Escolas Sociológicas e o Realismo. B. O Sistema Policêntrico. 1. A Descodificação. 2. As Reformulaçōes Contemporâneas. Conclusão.

\section{Introdução}

Em toda teoria do conhecimento se faz um questionamento básico: é o universo um cosmos ou um cãos? Constitui o universo um sistema ordenado ou uma acumulação de elementos que se encontram em confusão, em desordem?.

E possível se estabelecer este mesmo questionamento no âmbito da teoria do $\mathrm{Di}$ reito e, em particular, na teoria do Direito privado.

A esse respeito, o Curso de Pós-Graduação - Mestrado em Direito da Universidade Federal do Rio Grande do Sul tem respondido tomando partido entre os que consideram o Direito como um sistema e propondo aprofundar a investigação de temas concretos na matéria. Cumpre neste estudo analisar se a noção de sistema permite atribuir um caráter unitário ao Direito privado ou se deve admitir que o sistema do Direito privado tem um caráter pluralista.

Previamente, deve advertir-se para algum dos obstáculos que se enfrentam num estudo específico do tema. Para começar, a própria noção mesma de sistema da qual se utilizam os diferentes autores, não é coincidente. A palavra sistema sofreu uma evolução semântica muito importante através da história da Ciência e do Direito, analisada em profundidade por Losano, na sua obra Sistema e Struttura nel Diritto ${ }^{1}$.

Aliás, num mesmo momento histórico, os autores se referem a coisas diversas quan- 
do empregam a palavra sistema. Neste sentido, Friedrich Carl von Savigny (1779. 1861) advertiu a distinção entre sistema interno e sistema externo: é interno o sistema imanente nas próprias regras de Direito; externo, aquele construído pelo intérprete e pela doutrina jurídica ${ }^{2}$. Modernamente, est distinção encontra expressão numa outra distinção, mais genérica, feita por Losano, entre o sistema de objetos do conhecimento e o sistema de conhecimentos em si mesmo aos que se refere como sistema real e sistema ideal $^{3}$

O Direito, enquanto objeto do conhecimento, dispoe de uma sistemática interna, quando entre os elementos que o compoem pode se descobrir um nexo que os relacione de tal forma a estruturar uma ordem. Esta classe de sistema tem sido teorizada por vários autores. Alguns, como Gustav Radbruch, propoem o tema em termos filosóficos. Outros, como Rudolf Stammler, intentam determinar o sistema interno do Direito. Cada autor propoe, a este respeito, uma teoria diversa dos demais, até que se alcança a forma arquetípica de sistema in terno na Teoria Pura do Direito de Han Kelsen ${ }^{4}$.

O Direito, como sistema de conhecimentos, supoe a complexidade dos elemento normativos que o compoem, mas admite existência de um nexo de caráter lógico-racional que seja capaz de estruturá-lo como uma ordem. Esta classe de sistema também tem sido teorizada por vários autores. $\mathrm{Al}$ guns, como Kant, também propoem o tem em termos filosóficos, definindo o sistem como "a unidade, sob uma idéia, de conhecimentos variados" ou "um conjunto de conhecimentos ordenado segundo princípios". Outros intentam determinar o sistema externo do Direito, definindo o sistema como uma "concatenação interior que liga todos os institutos jurídicos e as regra de Direito numa grande unidade" (Friedrich Carl von Savigny) ou bem como "um conjunto de conceitos jurídicos ordenado segundo pontos de vista unitários" (Julius Binder) ou como uma "ordenação de conhe202 cimentos segundo um ponto de vista unitáio" (Helmut Coing).

Ambas noções de sistema, expressam uma contradição que a doutrina tem tentado conciliar. Em lugar de qualificá-las como categorias irredutíveis, se tem pretendido considerá-las como perspectivas de um mesmo fenameno, que se encontra em uma situação de interconexão e dependência recíproca. O sistema externo deve corresponder, o mais fielmente possível, ao sistema interno, de tal modo que a elaboração científica do objeto não desvirtue seu conhecimento, falseando, com isso, a sua finalidade. Vice-ver $s a$, a elaboração científica de um sistema jurídico, só se justifica quando seu objeto, isto é, o conjunto normativo, se apresenta como um sistema ${ }^{6}$. Nesta exposição, se participará do esforço para conciliar as noções de sistema externo e de sistema interno.

Como uma última precisão, admito que talvez fosse preferível uma exposição sinusoidal, destacando todas as exceções, idas e vindas da concepção unitária ou pluralista. Porém, para efeito de alcançar uma maior claridade nesta análise, realizarei uma exposição temporalmente linear, acorde com os postulados da teoria evolutiva dos sistemas $^{7}$.

$\mathrm{Na}$ primeira parte deste trabalho, estudar-se-á o fundamento teórico da noção de sistema único e sua consagração positiva (I). Em seguida, se verá como, no século presente, a unidade do Direito privado entra em crise, surgindo, em seu lugar, uma pluralidade de sistemás ou um sistema policêntrico (II). Reservo para as conclusoes o balanço atual do processo histórico de sístole e diástole que tem acompanhado a noção de sistema no Direito privado, principalmente quanto a unidade ou multiplicidade intra- sistemática.

I. O Direito privado como sistema único Un système n'est autre chose que la disposition des différentes parties d'un art ou d'une science dans un ordre où les dernières s'expliquent par les premieres. Celles que rendent raison des autres s'apellent principes; et le système est d'autant plus parfait que les principes sont en plus petit nombre; il est même à soubaiter $q u$ 'on les réduise à un seul.

Condillac, Traité des Systèmes, I, 121.

O Direito privado tardou em se manifestar como um sistema externo. A evolução do Direito romano, por exemplo, efetuou-se através da obra dos pretores, dos juristas práticos e do concílio do imperador romano e não por meio de leis com vocação compreensiva ${ }^{8}$. Os chamados colfy romanos ${ }^{9}$, não passariam de compilações referentes à totalidade do direito tanto público quanto privado, agrupando leis sobre coisas máximas e mínimas ${ }^{10}$

Cabe observar, entretanto, que estas compilações, o Digesto em particular, estavam dotadas de um sistemática interna. "As soluções aí reunidas - afirma Cordeiro -, tinham uma lógica imanente: procurando tratar o igual de modo igual e o diferente de modo diferente, de acordo com a medida da diferença, elas atingiram uma adequação formal que assegura a atualidade de muitas delas até os nossos dias"11.

O caráter heterogêneo e abarcante do Direito romano, guiado pela idéia de unidade e concentração, é retomado no século $\mathrm{XV}$ pelo Corpus Iuris Canonici (1437) e por outras grandes codificações compreensivas de todo o sistema jurídico de um Reino ou de um Estado. No Direito português temos - exemplo das Ordenações Alfonsinas $(1446)^{12}$. A partir do século XVI reaparece a palavra codex com a coleção denominada Codex Statutorum, de 1547, que recolhe os Statuti da cidade italiana de Alexandria ${ }^{13}$ Porém, estas compilações foram fruto de uma Jurisprudência medieval pré-sistemáti$\mathrm{ca}$, sendo que o principal era a interpretação dos problemas individuais.

A passagem da mera compilação de normas à configuração de um sistema, dependeu do renascimento do estudo dos filósofos gregos e dos juristas romanos da época Ciceroniana ${ }^{14}$. Houve então uma renovação pedagógica e metodológica, de tipo empírico e periférico. Faltava, entretanto, um vigoroso discurso teórico que transcendendo as contingências dos contatos superficiais entre temas jurídicos, permitisse um verdadeiro sistema externo de Direito. O discurso teórico referido, alcançado por importantes obras científico-filosóficas como a de Gottfried Wilhelm Leibniz e René Descartes (1596-1650), permitiria configurar o Direito privado como um sistema único ${ }^{15}$.

\section{A. A configuração teórica da noção de} sistema único.

O pensamento cartesiano seguiu um processo totalmente inverso do preconizado pela Escolástica e pelo Humanismo. Prescindiu dos elementos histórico-culturais, substituindo-os, simplesmente, pela razão ${ }^{16}$. Esta permitiria que o edifício das Ciências humanas assentasse em alguns poucos postulados, dos quais se deduziria o resto dos elementos que compoem o sistema. Alcançou-se, assim, o que a doutrina moderna denomina "segunda sistemática", de caráter central ${ }^{17}$.

A partir de então, o Direito privado conseguiu se configurar segundo um modelo de sistema axiomático-dedutivo. $\mathrm{O}$ sistema axiomático-dedutivo pressupoe que todas as proposições válidas dentro de um determinado âmbito material se deixem deduzir de axiomas, através de uma dedução puramente lógico-formal ${ }^{18}$. Para tanto, seria necessário reunir pelo menos duas exigências: ausência de contradições e completude ${ }^{19}$.

A concepção axiomático-dedutiva, porém, não foi unitária, dependendo sua formulação da corrente de pensamento que a adotou. O Jusracionalismo e o Positivismo divergem no que se refere à natureza dos axiomas em que se fundamenta o sistema. $O$ idealismo alemão retoma o questionamento em torno da idéia de unidade do sistema, influenciando em uas correntes fundamentais do pensamento jurídico: a Escola Histórica do Direito e a Jurisprudência dos Conceitos.

\section{A concepção do jusracionalismo}

A recepção da teoria aristotélica da Ciência e a aplicação do método cartesiano, le- 
varam os juristas do século XVII a conceber o Direito como um sistema centralizado em torno de certos axiomas evidentes.

Em primeiro lugar, nesta concepção, o sistema jurídico teve como base certos axiomas que surgiam de evidências, a partir do mundo criado por um Deus racional, ou a partir da natureza do ser humano e até da natureza das coisas. Desenvolveu-se a noção do Direito natural como a base fundamental do pensamento jurídico. Neste sentido, o Direito natural conquista um posto proeminente com o livro De iure belli ac pacis (1625), de Grocio, porém ainda entrelaçado inegavelmente com a Teologia e a Filosofia. Só mais tarde, Puffendorf (1632-1694), assim como Thomasius (1655-1728) e Wolf (1679-1754), conseguiriam independentizar - Direito natural como disciplina jurídica ${ }^{20}$.

Em segundo lugar, o sistema consistia num desenvolvimento dedutivo lógico-matemático - daí mos geometricus - desses axiomas evidentes. Neste sentido foi que Leibniz declarou que o Direito pertencia àquelas disciplinas que não dependiam da experiência senão de definições; nem de fatos, senão de uma prova lógica estrita. O Direito seria redutível a uma pura aritmética ${ }^{21}$.

Assim, o Direito natural instalou-se no âmbito do Direito privado como um conjunto de princípios jurídicos que integram uma construção lógica de grande rigor e que vêm a formar uma pirâmide cuja cúspide representa as normas de mais amplo alcance e generalidade ${ }^{22}$

Toda proposição jurídica era inferida logicamente e derivava sua verdade daqueles axiomas. Desta forma, a Ciência jurídica cumpria dois dos postulados que a teoria aristotélica impunha: a evidênicia e a dedução ${ }^{23}$.

A recepção estrita destes postulados, enfrentava a natureza histórico-cultural das realidades jurídicas, que, por sua vez, desafiavam as tentativas de redução lógica. Se o jusracionalismo houvesse insistido neste caminho, haveria fracassado necessariamente. Sem embargo, graças a autores como Samuel Pufendorf, abdicando de alcançar uma seqüência perfeita, o jusracionalismo 204 soube captar as realidades culturais subjacentes e apoiar seus desenvolvimentos lógicos no Direito Romano 24 .

Aliás, o Direito natural foi o padrão adeqüado para a valoração crítica do Direito romano, impulsionando o progresso e a reforma da vida jurídica, mesmo no Direito privado e apesar de seu caráter cónservador. Esta orientação seria logo desenvolvida por Domat (1625-1696) e, mais tarde, por Pothier (1699-1772), constituindo-se no suposto doutrinal básico da codificação ${ }^{25}$.

\section{A concepção do positivismo}

Ao final do século XVIII, produziu-se uma mudança importante na concepção do sistema jurídico. Basicamente, rejeitaram-se os princípios do Direito natural, o que supas o abandono do Postulado da Evidência $^{26}$. A base axiomática do sistema deixou de ser procurada na evidência racional ${ }^{27}$.

O Positivismo propas que, em seu lugar, fossem adotados os enunciados normativos promulgados pela autoridade, isto é, as normas criadas pelo legislador humano. A razão foi, assim, substituída pela experiência, pois os axiomas não se deduzem, eles são captados pela observância do Direito positivo $^{28}$.

Mantém-se, porém, a estrutura dedutiva do sistema. Dentro deste modelo, comum ao Jusracionalismo e ao Positivismo, foram de principal interesse as propriedades formais do sistema, tais como a coerência, a plenitude e a independência de seus axiomas $^{29}$.

A coerência do sistema implicava em que nelenãopoderiam existir antinomias. No caso de a aplicaçãoconcretado Direito fazer aflorar uma antinomia, considerava-se que esta revelava contradições somente aparentes, que o próprio sistema devia-se encarregar de excluir "a priori"130. Garantia-se assim, a clareza e a certeza do conhecimento jurídico ${ }^{31}$.

A noção de plenitude conduzia ao problema das lacunas do Direito. O sistema jurídico não poderia admitir a existência de lacunas ${ }^{32}$.
Toda a questão jurídica encontraria uma resposta dentro do sistema criado, alcançada mediante uma simples operação lógica de subjunção adequada. Desta forma, lograva-se um alto grau de segurança jurídica ${ }^{33}$.

Por último, a independência das normas que compunham o sistema impunha a supressão das redundâncias ${ }^{34}$

\section{O idealismo alemão e suas vertentes} jurídicas

A idéia de sistema mergulha suas raízes na filosofia do idealismo alemão. Fichte e Schelling tentaram apreender conceitulamente o Mundo, a partir de um último princípio "transcendental". Hegel buscou apresentar o "verdadeiro" como "todo", isto é, como o movimento do conceito "concreto" girando sobre si próprio e superando o respectivo contrário. Ensina Karl Larenz: "O sistema significa, pois, aqui, muito mais do que mera clareza e facilidade de domínio de uma certa matéria; significa a única maneira possível por que o espírito cognoscente consegue ficar seguro da verdade: o critério $\mathrm{da}$ racionalidade intrínseca, preocupação imprescindível da verdadeira cientificidade. ${ }^{.35}$

A unidade que o sistema há de exprimir foi pensada de duas maneiras diferentes. $\AA$ maneira de um "organismo", os elementos constitutivos do sistema congregam-se, todos eles, em volta de um centro. A "unidade" do sistema repousa na irredutível relação de todos os elementos constitutivos com esse centro fundado em si próprio. Aqui teve sua base a noção de sistema de que se valeu a Escola Histórica do Direito ${ }^{36}$.

A maneira da lógica formal, a "unidade" do sistema repousa no conceito geral "abstrato". O sistema de conceitos determina-se pelos princípios da lógica formal, assemelhando-se a uma pirâmide. Aqui teve sua base a noção de sistema de que se valeu a Jurisprudência dos conceitos ${ }^{37}$.

\section{a. A concepção da escola histórica do direito}

A Escola Histórica do Direito reage contra a concepção jusracionalista do Direito.
No prólogo da Revista para a Ciência do Histórica do Direito (Zeischrift für geschichtliche Rechtswissenschaft) do ano 1815, Savigny (1779-1861) descreve um programa de aberta oposição à tendência jusracionalista. Porém se abstém de formular uma consideração crítica sobre o Direito natural ${ }^{38}$.

A confontação teórica centra-se contra a doutrina positivista do Direito. Esta confrontação se faz visível no célebre escrito de Savigny: Sobre a vocação do nosso tempo para a legislação e a Ciência do Direito (Von Beruf unserer Zeit für Gesetzgebung und Recbtswissenschaft, 1814). Savigny considera como fonte originária do Direito, já não a lei, mas a comum conviç̧ão jurídica do povo, $\circ$ "espírito do povo" 39 .

Por isso, Savigny opoe a Thibaut que todas as codificações seriam "inorgânicas" e, por isso, ou prejudiciais ou inúteis; o Direito só se configuraria de forma "orgânica" a partir das convicções do povo. O caráter "orgânico" do instituto jurídico, só pode ser compreendido na concepção que Schelling usou o conceito de "organismo", como uma categoria geral e não simplesmente biológi$\mathrm{ca}^{40}$. Por sua vez "povo", para Friedrich von Savigny, constituia um conceito cultural, representado pelos juízes e letrados de um país ${ }^{41}$.

Porém, o jurista não elabora o Direito; somente reconhece e expoe o Direito. Daí que seja preciso uma teoria da interpretação sistemática. Esta teoria foi exposta por Savigny no Sistema do Direito Romano atual (System des heutigen römischen Rechts, 1840): "Eu coloco a essência do método sistemático no reconhecimento e na exposição da íntima ligação ou da afinidade pela qual os singulares conceitos jurídicos $e$ as singulares regras são conexas numa grande unidade ${ }^{142}$

$\mathrm{Na}$ verdade, Savigny se opas às sugerências de Thibaut, não por ser inimigo, por princípio, de toda codificação, mas por entender que a Ciência jurídica alema não estava preparada para sevir de suporte a um Código Civil. Por outra parte, SAVIGNY temia a influência do Code civil, tanto por seu caráter revolucionário como por motivos nacionais ${ }^{43}$ 
Prova disso foi a atuação prática da Escola Histórica na legislação e sua influência em algumas codificações, com por exemplo, o Código Comercial alemão de 1861, o Código Civil saxão de 1863 e, fundamentalmente o Código Civil alemão de 1900 (BGB) $)^{44}$

\section{b. A concepção da jurisprudência dos} conceitos

Georg Friedrich Puchta (1798-1846) con clamou a Ciência jurídica do seu tempo a tomar o caminho de um sistema lógico no estilo de uma "pirâmide de conceitos", cons truído segundo as regras da lógica formal. Portanto, possui o "conhecimento sistemá tico" quem "consegue seguir, tanto no sen tido ascendente como no descendente, proveniência de cada conceito através de todos os termos médios que participam na sua formação" 45 .

Por sua vez, a legitimidade da norma jurídica baseia-se, exclusivamente, na su correção sistemática, na sua verdade lógic e na sua racionalidade. A própria criação do Direito torna-se "desenvolvimento a parti do conceito"46.

Isto é, a construção dedutiva do sistem depende, absolutamente, da pressuposição de um conceito fundamental, conceito que não é, por sua vez, inferido do Direito positivo, mas dado previamente à Ciência jurídica pela filosofia do Direito. Porém, influência da filosofia se limita a determinação do conteúdo do conceito fundamen tal. A maneira como Georg Friedrich Puch ta constrói os conceitos ulteriores, ou seja o processo lógico- dedutivo, deriva do racionalismo do século XVIII, em especial do pensamento de Christian Wolff. Este processo lógico-dedutivo da "Jurisprudência dos conceitos", preparando o terreno ao "formalismo" jurídico que viria prevalece durante mais de um século ${ }^{47}$.

\section{B. A consagração da noção de sistema} único no Direito Positivo

O Iluminismo objetivou, desde o século XVIII, a formulação de leis positivas que consagraram "o direito justo reclamado pela 206 razão universal dos povos ${ }^{\prime \prime 4}$. Esta meta pode ser alcançada em virtude da nova configuração da noção de sistema e de especialíssimas instâncias sócio-políticas, que culminaram com o fenameno da codificação ${ }^{49}$. No final do século XVIII e no início do século XIX, apareceram as chamadas "codificações jus- racionalistas" ou "do Iluminismo" e, no final do século XIX, o Código Civil alemão (Bürgerliches Gesetzbuch)

\section{As codificações jusracionalistas}

No final do século XVIII, o panorama do Direito positivo europeu começou a alterar-se fundamentalmente. As recompilções de normas jurídicas heterogêneas em um único corpo, começaram a se desagregar.

A organização do Estado, do Governo e as garantias dos indivíduos passaram a ser objeto de um código autanomo e superior aos outros, denominado "constituição". O Direito privado, entretanto, passou a ser objeto das leis ordinárias ${ }^{50}$.

Desde então, teve início uma forte tendência em direção à codificação sistemática do Direito privado.

\section{O Código prussiano}

$O$ primeiro fruto da tendência recém assinalada, foi o "Direito Territorial Geral dos Estados da Prússia" (Algemeines Landrecht), publicado a 5 de fevereiro de 1794. O Código correspondia ao mais genuíno esquema do "despotismo iluminista" do, também, o de maior inspiração jusracionalista. Pretendeu regular minuciosamente, até os últimos detalhes, tanto em Direito público como em Direito privado, com intenção manifesta de eliminar toda jurisprudência criadora e de prescindir da Ciência jurídica. Por outro lado, deixou subsistentes os Direitos territoriais e locais dos diversos Estados prussianos ${ }^{52}$

\section{b. O Código Civil austríaco}

O A.B.G.B. (Österreichisches Allgemeines Bürgerliches Gesetzbuch), "Código Civil Geral austríaco", foi também um produto típico do despotismo iluminista. Sem tantas pretensoes como o Código prussiano, constituiu um código somente de Direito privado, de redação clara e conceitos precisos ${ }^{53}$.

\section{c. O Código napoleanico}

O Código Civil francês de 1804 foi o mais representativo das codificações jusracionalistas e aquele que tem tido maior e mais duradoura influência ${ }^{54}$.

Do ponto de vista sócio-político, esta sistematização do Direito privado é interpretada como uma operação política adequada a um programa de mudança estrutural da sociedade ${ }^{55}$. Com efeito, o Código Civil napoleanico deu plena satisfação aos ideais políticos, econamicos e sociais da Revolução Francesa. A concepção abstrata dos direitos individuais e, em especial, a ampla tutela do direito de propriedade, demonstram que, apesar de sua aparente neutralidade, o Código Civil foi a expressão do liberalismo conservador. Neste sentido, foi considerado Código da burguesia ${ }^{56}$.

Do ponto de vista técnico-jurídico, o Código Civil francês foi fruto do trabalho levado a cabo nos séculos XVII e XVIII, principalmente por Domat e por Pothier ${ }^{57}$. Seu mérito principal constituiu, essencialmente, no abandono da antiga técnica dirigida simplesmente a coordenar e conciliar os textos do Direito romano ou dos coutumes ${ }^{58}$. Em seu lugar, elaborou-se um sistema externo ${ }^{5}$ - conforme os postulados da segunda sistemática, como conjunto dotado de certa estrutura, onde o encadeamento de cada uma de suas partes fundava-se na subordinação a um princípio, uma idéia ou uma lei superior ${ }^{60}$. Enquanto expressão da própria razão, pretendia compreender todas as hipóteses possíveis ${ }^{61}$

Naquilo que tange a sua estrutura, o Código napoleanico consta de um título preliminar e de três livros: livro I, "Das pessoas", livro II, "Dos bens e das diversas modificações da propriedade", livro III, "Das diferentes formas pelas quais se adquire a propriedade". Seus grandes pilares residem nos artigos 544 e $1134 / 1$ que se expressam da seguinte forma: "A propriedade é o direito de gozar e de dispor dos bens da forma mais absoluta, desde que não se faça deles um uso proibido pelas leis o pelos regulamentos" e "As convenções legalmente formadas valem como leis para aqueles que as fizerem

As normas do Direito privado que se encontravam incluídas em outros códigos ou em leis separadas, classificaram-se em alguma das seguintes categorias: leis especiais ou leis excepcionais. As leis especiais aplicavam os princípios enunciados no Código Civil a respeito de uma matéria específica, sua separação do Código Civil era meramente formal. As leis excepcionais, pelo contrário, apartavam-se dos princípios contidos no Código Civil, mas não constituiam mais que rupturas efêmeras ${ }^{63}$.

$\mathrm{Na}$ América Latina, durante o século XIX, a configuração do Direito privado como sistema único, teve como modelo o Código Civil francês. De Los Mozos denomina este fenameno de "codificação afrancesada". Estas codificações caracterizavamse por terem assimilado o Código napoleanico com escassas modificações. Encontram-se entre elas, o Código Civil do Haiti (1835), da Bolívia (1834-1845), do Perú (1851), da República Dominicana (1864), do Uruguai (1868), da Venezuela (1873), da Guatemala (1877), de El Salvador (1800), de Honduras (1887) e da Costa Rica (1887) ${ }^{64}$.

A esta época pertenceu também o Código Civil chileno (1857), o Código Civil argentino (1869) e o Esboço de Teixeira de Freitas (1860-1865). Nestes, a influência do modelo francês não se limitou a uma mera assimilação passiva posto que seus autores criaram obras dotadas de originalidade ${ }^{65}$.

\section{O Código Civil alemão}

A variedade de legislações particulares que vigiam no território do Sacro Romano Império da nação germânica, alentava a tarefa de elaborar um Código Civil que fosse de aplicação geral. Porém, nesse primeiro momento, a tarefa encontrou uma tenaz resistência na Escola Histórica que, no es- 
sencial, argumentou com a falta de maturidade jurídica e política para levar a cabo a codificação ${ }^{66}$

Por essa razão, a sistematização do Direito privado germânico viu-se demorada até fins do século XIX. Só então, uma vez reconstruído o Império, sob a égide da Prússia, e tendo a lei de 20 de dezembro de 1873 declarado matéria federal o Direito civil consideraram-se cumpridos os presupostos exigidos pela Escola Histórica do Direito para a codificação ${ }^{67}$.

Um dos projetos elaborados com base na lei de 1873, foi aprovado pelo Parlamento em 1 de julho de 1896 e entrou em vigor em 1 de janeiro de $1900^{68}$

Como resultado desta aparição tardia do B.G.B., tratou-se de uma sistematização de idéias jurídicas consagradas já como evidentes ${ }^{69}$. Desde sua origem apresentou-se antiquado e distanciado da realidade, por dirigir-se à burguesia, ao pequeno industrial e ao camponês, consagrando as idéias do individualismo. Somente em alguns pontos logrou que se introduzissem alguns preceitos de caráter social devido às críticas formuladas por Otto von Gierke e por Anton Menger ${ }^{70}$. Por esta razão, Wieacker considerou o B.G.B. como "o filho tardio do liberalismo clássico"71.

Como contrapartida, o B.G.B. tem sido considerado a mais refinada formulação jurídica do pensamento liberal do século $\mathrm{XIX}^{72}$. Voltado para a abstração, o B.G.B. esforçou-se em lograr um sistema sem lacunas, conseqüente com os ditames da jurisprudência conceitual. Mas isto não foi obstáculo para que, em pontos decisivos, fossem utilizadas cláusulas gerais inteligentemente concebidas. Estas cláusulas asseguraram a abertura permanente do sistema às exigências mutáveis do comércio jurídico $e$ permitiram o ingresso de novos fatores no ordenamento ${ }^{73}$.

Por outro lado, o B.G.B consagrou positivamente o "Plano Savigny", ainda que lhe tenha introduzido uma pequena modificação, ao dispor primeiramente sobre o tratado das obrigações e, depois, sobre o tratado dos direitos reais. Além disso, tanto esta 208 matéria concernente aos direitos reais, como a matéria concernente ao regime matrimonial de bens e grande parte do Direito sucessório, foram tomadas do Direito propriamente alemão, pelo qual não pode se

Finalmente,é de se destacar, como uma inovação particular deste código, tendente a alcançar a unidade sistemática do Direito civil, a incorporação de uma "parte geral", procedente da Pandectística. Nesta "parte geral", agruparam-se as disposições comun aos diferentes ramos do Direito civil: as regras concernentes à capacidade das pessoas, aos atos jurídicos, ao cumprimento dos prazos e à prescrição ${ }^{75}$. Garantiu-se, deste modo, a coerência intelectual e metodológica do sistema ${ }^{76}$

$\mathrm{Na}$ América Latina, o B.G.B. influiu, marcadamente,sobreas chamadas "codificações tardias". Destacam-se entre elas, o Código Civil brasileiro (1916), o mexicano (1928) e o peruano $(1938)^{77}$.

$\mathrm{Na}$ Europa consideram-se como "codificações tardias", o Código Civil suíço (1907) o grego (1940), o italiano (1942) e o português (1966). Todos estes códigos - como o B.G.B. - foram fruto da chamada terceira sistemática, correspondendo, entretanto, a uma certa universalização do Direito e da sua Ciência. Consideraram as críticas setoriais feitas tanto à codificação francesa quanto à alema e consagraram institutos novos (por exemplo, o abuso do direito, a alteração das circunstâncias e a violação positiva do contrato) ${ }^{78}$.

\section{O Direito Privado como uma} pluralidade de sistemas,

Desconfia de todos os sistemáticos e os evita. $O$ gosto pelo sistema é uma falta de probidade.

Friedrich Wilhelm Nietsche, O Crepúsculo dos ídolos, Sentenças e dardos (1888).

A pesar do entusiasmo codificador com que terminou o século XIX e começou o século XX, a noção de sistema foi objeto de permanentes questionamentos de caráter epistemológico, tanto no âmbito da Teoria do Direito como no da Teoria da Ciência e do Conhecimento em geral.

No final do século XIX, com a invenção das geometrias não- euclideanas, transformou-se o conceito da teoria axiomática. Compreendeu-se que um dado sistema de símbolos e sentenças pode admitir mais d uma interpretação. Neste modo, se poderi usar uma só linguagem para fazer referência a variados domínios. As definições iniciais não seriam apenas desnecessárias, como, em certo sentido, impróprias ${ }^{79}$

Também o método dedutivo-formal revelou-se uma base não inteiramente satisfatória para todas as teorias da Matemática. Nesse sentido, Gödel, em 1931, demostra que inúmeras teorias eram incompletas ${ }^{80}$

Desde o âmbito da Teoria do Conhecimento em geral, o pragmatismo, por exemplo, nega a idéia de unidade. Dizia James, em 1907: "O pragmatismo, fazendo depender a determinação empírica final do que possa ser o equilíbrio da união e da desunião entre as coisas, tem que se colocar do lado pluralista. Admite que se poderia chegar, algum dia, em que até a união total, com um conhecedor, uma origem, e um universo consolidado de todas as formas concebíveis, fosse a mais aceitável das hipóteses. Entretanto, a hipótese oposta, de um mundo todavia imperfeitamente unificado e talvez destinado a persistir assim,indefinidamente, deve ser sustentada sinceramente..." ${ }^{\prime \prime}$

O filósofo e jurista uruguaio Vaz Ferreira, em 1910, considerava a própria noção de sistema, como uma espécie de vício intelectual: "... el espíritu humano todo lo completa, todo lo simetriza, es como esos caleidoscópios de los niños, en que cada piedrita de colores se multiplica varias veces, por todos los lados, simétricamente, y donde es imposíble, por mas que se agite la arena, obtener una figura asimétrica o incompleta..." ${ }^{182}$. Adverte, assimesmo, os peligros do "paralogismo de falsa sistematização", aconselhando restringir o pensamento sistemático a "... allí donde: primero, se sabe todo lo de hecho y lo de principio; esto es: cuando se poseen bien todos los datos de la cues- tión, todos los principios que deben ser aplicados; y segundo: cuando, todo esto se puede combinar, integrar - diremos - en el sistema...". Vaz Ferreira cita como exemplos as matemáticas e a mecánica ${ }^{83}$.

No âmbito da Teoria do Direito surgiram várias escolas que refutaram as pretensoes de plenitude e de unidade do sistema jurídico que se mantinham desde o século XVI. No fundamental, foram rebatidas suas três propriedades básicas: plenitude, coerência e independência $(A)$.

Por sua vez, o Direito não suportou a pressão de diversos fatores políticos, econamicos e sociais, que acompanhou a primeira metade do século XX. Em conseqüência, o sistema de Direito privado consagrado no Código Civil desintegrou-se rapidamente, dando lugar à formação de uma pluralidade de sistemas (B)

\section{A. A refutação teórica da noção de} sistema único

No século XIX, ainda quando a criação do Direito transitou para as maos do legislador, persistia uma Ciência jurídica baseada em certos pressupostos éticos e ligada com uma cultura jurídica eticamente fundada. A legislação continuava confiada aos representantes desta cultura, aos letrados e aos juristas formados tecnicamente ${ }^{84}$

No século XX, a Lei já não se legitima por uma idéia de justiça situada acima do Direito, mas como produto de meios e de fins da realidade imanente. Neste sentido, uma das tendências condutoras da evolução do Direito foi uma nova concepção das relações da ordem jurídica com a realidade social e uma convicção da responsabilidade ético-social da ordem jurídica positiva. Esta tendência fundava-se na "naturalização" da concepção do Direito, a partir de uma interpretação causal da realidade ${ }^{85}$.

Ao florescimento do naturalismo jurídico deve-se o surgimento da sociologia do Direito e do realismo. No seio da dogmática do Direito privado, o naturalismo propiciou novas tendências metodológicas, entre as quais a Jurisprudência dos Interesses. A 
explicação causal do Direito enquanto Ciência da realidade influiu, também, no movimento do Direito livre ${ }^{86}$.

\section{O movimento do direito livre}

A escola do Direito livre foi proclamada na Alemanha por Ernst Fuchs e Hermann Kantorowicz e, na França, encabeçada por François Gény. Constituiu uma reação a um tempo contra o positivismo legal e contra a jurisprudência conceitual. A estes opas que a decisão jurisprudencial se baseava, não em processos intelectuais, mas em processos intuitivos, sobretudo assentes nos sentimentos do juiz. Em razão disso que o juiz esteja legitimado e mesmo obrigado a desviar-se da lei sempre que considerar injusta ou inadequada a sua aplicação a um dado caso $^{87}$

François Geny, no seu tratado Méthode d'Interpretation et Sources en Droit Privé Positif, afirmou que o juiz sempre possui uma esfera mais ou menos ampla de livre discricionariedade, dentro da qual pode exercer uma atividade criadora. Esta atividade deveria se basear na livre investigação científica (livre recherche scientifique) $^{88}$.

Conseqüentemente, os partidários do $\mathrm{Di}$ reito livre negaram a plenitude do sistema. Sustentaram que no Direito existem lacunas que cabe ao juiz completar. Para isso, o juiz deveria recorrer a uma fonte alheia ao Direito positivo. Por esta razão, o movimento foi considerado como uma intenção de par em prática o conceito stammleriano de um Direito natural de conteúdo variável.

Hermann Kantorowicz questionava a plenitude do sistema dedutivo nos seguintes termos: "Em nenhuma Ciência teórica ou prática existe a crença de que um dia pudesse ser capaz, e muito menos, que já o fosse, de resolver qualquer problema imaginável. O biólogo, o astranomo, o filósofo, o historiador, o esteta, não nega em momento nenhum que somente saberia contestar a um número de questoes insignificantes em comparação com a totalidade das interrogantes ... Somente a jurisprudência se atre210 ve, a causa de sua suposta plenitude hermética, a poder resolver qualquer problema real ou imaginável e exige esta capacidade, inclusive, do último de seus novatos"89.

\section{A jurisprudência dos interesses}

Os representantes principais da Jurisprudência dos Interesses foram Rudolf Jhering Philipp Heck, Heinrich Stoll e Rudolf Müller-Erzbach. Estes autores consideram o Direito como "tutela de interesses". Isto é, as leis são "as resultantes dos interesses de ordem material, nacional, religiosa e ética, que, em cada comunidade jurídica, se contrapoem uns aos outros e lutam pelo seu reconhecimento"

Em matéria de construção dos conceitos e do sistema, a maior preocupação da Jurisprudência dos Interesses consistiu em mostrar que o sistema lógico-formal de conceitos gerais abstratos, não deve utilizar-se como fonte de conhecimento de novas proposições jurídicas ${ }^{91}$

Para tanto, Philipp Heck contrapas as noções de sistema interno e de sistema externo, para concluir, em definitivo, pela irrelevância do segundo ${ }^{92}$.

Ao sistema externo Heck atribui apenas um valor de exposição, não um valor de cognição. Só deve servir para "a formulação e a ordenação extrínseca" do material jurídico ${ }^{93}$

Por sua vez, o sistema interno resultaria do nexo objetivo entre as soluçōes dos problemas que propicia a investigação dos interesses. Heck insiste, porém, em voltar à idéia de um sistema de normas como um sistema de "decisoes de conflito" 94

A partir de então, a sua análise do Direito concentrava-se na discussão do problema singular e não na elaboração do sistema. Por isso, em definitivo, o Direito não era pensado pela Jurisprudência dos Interesses como uma ordem unitária ${ }^{95}$. A concepção do Direito como um "sistema de decisoes de conflitos", não diz praticamente nada sobre a unidade do Direito. "Também - segundo CANARIS - na tomada de posição de Heck quanto a problemas práticos e sin- gulares do sistema se mostram quão estranha the é, no fundo, a conexão entre o sistema e a idéia da unidade de sentido do Direito". ${ }^{96}$

Precisamente em virtude desta auto-resig nação a uma função técnica, a Jurisprudência dos Interesses adquiriu um elevado valor prático e um largo reconhecimento no plano científico e no plano da prática. WIEACKER lembra, porém, as limitações da Jurisprudência dos Interesses, uma vez que ao analisar simplesmente os interesse pré-estabelecidos e preferidos pelo legislador para seguir sua valoração, não dava ao juiz qualquer indicação para o caso em que a lei não tivesse procedido a uma tal valoração. "Nestes casos-fronteira - continua Wieacker - a jurisprudência dos interesses que se mantenha fiel à lei, fica até mais desarmada do que um naturalismo radica que não fosse encaminhado para uma ime diata descrição dos valores mais elevados da vida e da sociedade" ${ }^{1197}$.

3. As escolas sociológicas e o realismo

As correntes acima comentadas, contribuiram para o desenvolvimento de um profundo interesse pelas bases sociais e econamicas do Direito e pela realidade da vida jurídica, o qual promoveu uma mudança de rumo na Ciência jurídica, que se voltou à sociologia ${ }^{98}$. Surgiram então vários movimentos que buscaram erguer uma Ciência jurídica de base empírica: as diversas escolas sociológicas (León Duguit e Raymond Saleilles na França, Roscoe Pound nos Estados Unidos de América), o realismo norte-americano (Oliver W. Holmes, Benjamín Cardozo, J. Gray, K. Llewellyn, Jerome Frank) e o escandinavo (Hagerstrom, Lundsteat, Olivecrona, Alf Ross) ${ }^{99}$.

As escolas sociológicas renovaram a teoria da interpretação da lei, a partir da definição do Direito como função social ${ }^{100} \mathrm{Me}$ todologicamente caracterizavam-se pela rejeição do método racional-dedutivo. Em consonância com esta rejeição, a conquista principal do racionalismo, a noção de sistema, foi abandonada ${ }^{101}$.
De acordo com Oliver Holmes, "A vida do direito não tem sido a lógica, senão a experiência As necessidades sentidas na época, as teorias políticas e morais predominantes, as instituições acerca do interesse público - confessadas ou inconscientes -, inclusive os pré-juízos que os juízes compartem com seus concidadãos, têm tido muito mais influência do que o silogismo, na determinação das normas pelas quais deviam ser governados os homens. O Direito encarna a história do desenvolvimento de uma nação no decorrer de muitos séculos e não pode ser tratado como se contivesse unicamente os corolários de um livro de matemática"102.

\section{B. O sistema policentrico}

A decadência da organização econamica liberal correspondeu à destruição de sua maior criação jurídica: a unidade do Direito privado, como um sistema fechado capaz de conter, em si mesmo, a solução de todos os problemas jurídicos ${ }^{103}$.

\section{A descodificação}

A Primeira Guerra Mundial (1914-1918) gerou situações de carência - como, por exemplo, em matéria de habitação - que não podiam ser solucionadas de acordo com os princípios tradicionais contidos no Código Civil. No caso mencionado o legislador viuse obrigado a introduzir graves restrições à liberdade de contratar. Desta forma, as leis do inquilinato integram uma legislação excepcional, que contradizia o axioma da autonomia da vontade ${ }^{104}$

Contemporaneamente, o fluxo crescente das massas operárias aos grandes centros urbanos, conduziu a que se substituisse a disciplina tradicional do contrato de trabalho. Em seu lugar, formou-se outro conjunto de normas de caráter excepcional, oposto ao prícipio da liberdade contratual. A progressiva inserção das máquinas na fabricação, levou também à rejeição da regra clássica da responsabilidade civil subjetiva ${ }^{105}$.

Outra matéria a atingir independência foi o Direito de Família. A primeira lei 
autanoma a respeito foi a "Lei Federal do México sobre as Relações de Família" (1917) ${ }^{106}$.

$\mathrm{O}$ mesmo processo repetiu-se, posteriormente, no Direito Econamico ${ }^{107}$.

No início da segunda metade do século XX, a concepção do Direito privado como sistema único tornou-se insustentável. $\mathrm{O}$ Código Civil não estava em condições de garantir a unidade do sistema. As leis especiais não se apresentavam, então, como simples desenvolvimentos do Código Civil; ao contrário, continham princípios autanomos que os separavam de toda conexão com o Código Civil.

Paulatinamente, as leis especiais e excepcionais - que tinham por objetivo regular fenamenos jurídicos extra-código - invadiram o território do Código Civil, acabando por expropriar matérias que lhe eram próprias. As chamadas "leis descodificantes" começaram a esgotar o conteúdo do Código Civil, convertendo-o na sede das normas mais gerais do Direito privado (normas sobre os requisitos dos contratos ou sobre a tutela do direito, por exemplo)

Por outro lado, assistiu-se a um processo de consolidação das chamadas leis especiais e excepcionais. Esta consolidação criou micro-sistemas de normas dotados de organização e lógica autanomas.

Desta forma, o Código Civil que era "a lei civil", converteu-se em "uma das leis civis" $^{1108}$. O Código Civil deixou de ser o vértice do sistema para se converter em parte de um poli- sistema ${ }^{109}$. Foi o fim do mono sistema, que deu passagem à coexistência de uma pluralidade de sistemas.

Cabe advertir que a noção de poli-sistema pretendeu resgatar a idéia de unidade, ao reconhecer a existência de normas e princípios gerais, comuns aos diversos micro-sistemas. Alguns autores italianos situaram estas normas e princípios gerais na Constituição.

A hierarquia desta fonte do Direito, assim como o rico conteúdo programático das modernas Constituições lhe permitira converter-se no vértice do sistema ${ }^{110}$

Também se pretendeu caracterizar novamente o Direito privado, em torno de um Código das Obrigações ou da "parte geral" 212 do Código Civil. Neste sentido, já em 1914 aparece no Brasil um anteprojeto de código das obrigações, obra de três civilistas: Orozimbo Nonato, Filadelfo Azevedo e Hahnemann Guimaraes. Um segundo anteprojeto de Código das obrigações foi concluído em 1963, obra do professor Caio Mário da Silva Pereira ${ }^{111}$

Em 1977, uma comissão integrada po Miguel Reale, José Carlos Moreira Alves, Agostinho Alvim, Sylvio Marcondes, Ebert Chamoun, Clóvis Veríssimo do Couto e Silva e Torquato Castro, apresentava um anteprojeto de Código Civil. Hoje trata-se do "Projeto de Lei n.554-B", em tramitação na Câmara dos Deputados. A respeito deste projeto, Martins Costa explica que "foi pensamento expresso dos juristas que o elaboraram transformá-lo em código central, revigorando, assim, processo tradicional do ordenamento de linhagem portuguesa, qual seja, o de adotar determinado corpus como ponto de referência indispensável à preservação da unidade do direito ..."112

O próprio Clóvis do Couto e Silva manifestou esta idéia em conferência proferida na Faculdade de Direito da Universidade de Florença,em 6 de maio de 1986: "O pensamento que norteou a comissão que elaborou o Projeto do Código Civil brasileiro foi o de realizar um Código central, no sentido que lhe deu Arthur Steinwenter, sem a pretensão de nele incluir a totalidade das leis em vigor no país. A importância está em dotar a sociedade de uma técnica legislativa e jurídica que possua uma unidade valorativa e conceitual, ao mesmo tempo em que infunda nas leis especiais essas virtudes, permitindo à doutrina poder integrá-las num sistema, entendida, entretanto, essa noção de um modo aberto."113

\section{As reformulações contemporâneas}

O próprio fenameno da descodificação motivou uma renovação metodológica, seja recorrendo a formas de pensamento abandonadas - como o pensamento tópico - seja reformulando as técnicas tradicionais. como faz a lógica moderna - ja por intermé- dio de novos conceitos - como o de "autopoiesis". Sem pretender esgotar as diversas modalidades que assume a referida renovação do método na Ciência do Direito moderno, analisarei brevemente as seguintes.

\section{a. O pensamento tópico}

$\mathrm{Na}$ concepção de Viehweg, o sistema axiomático-dedutivo não se adapta às particularidades do Direito. Viehweg sustenta esta afirmação em quatro planos. Em primeiro lugar, a eleição dos axiomas que lhe sirvam de base é arbitrária. Em segundo lugar, a aplicação do Direito requer extensoes, restriçōes, assimilações, concentrações e outros procedimentos similares. Em terceiro, a necessidade de se recorrer à linguagem, que é sempre multi-significativa. Em quarto, a apreensão dos fatos, condicionamento de qualquer solução jurídica, escapa às possibilidades do sistema axiomático-dedutivo ${ }^{114}$.

Viehweg entende, porém, que é igualmente necessária "uma diligente e constante reedificação e ampliação do direito", que cuide de que "o alicerce total da atividade jurídica conserve a sua estabilidade, sem perder flexibilidade". Aliás, essa reedificação e ampliação "forma o núcleo peculiar da arte do Direito"1115.

Para tanto, propoe atribuir à razão e à dedução uma função diferente. A dedução, na concepção de Viehweg, é imprescindível, mas não desempenha, de modo algum, um papel diretivo ${ }^{116}$

Viehweg considera que é preciso substituir o razoamento axiomático, pelo razoamento tópico. A base deste pensamento não estaria constituída por verdades, senão por premissas plausíveis e na eleição destas premissas ficaria o decisivo, como conseqüência de um modo determinado de entender o Direito, em atenção à aporia fundamental $^{117}$.

Subsistiria, então, uma estrutura, porém fundada nessas premissas. Nesta forma, a estrutura não seria prévia ao problema como acontece no sistema axiomático-dedutivo - senão que partiria do problema ${ }^{118}$ b. A concepção da lógica moderna

A renovação do interesse pela aplicação da lógica ao Direito é de origem relativamente recente e diretamente relacionado com o surgimento da lógica matemática ou simbólica. O primeiro a chamar a atenção dos juristas sobre a possibilidade de aplicar a lógica formal ao Direito, parece ter sido Walter Wheeler Cook, em 1927. Porém, a pesar de que na década de quarenta alguns uristas seguirem a indicação de Wheele Cook, só a partir da década de cinqüenta, começaram a desenvolver-se estudos basea dos numa revalorização dos métodos lógico-dedutivos, no contexto da moderna lógica proposicional ${ }^{119}$

Em 1951, Ulrich Klug, publica a primeira edição de Juristiche Logik. Ulrich Klug considerou o significado da idéia de sistema como uma demonstração essencial do peso do pensamento lógico-formal da Ciência do Direito. Para ele, os "processos de conclusão" jurídicos, como a analogia, a redução teleológica, o argumentum a fortiori e o argu mentum ad absurdum podem-se representar através da lógica moderna ${ }^{120}$

Em 1963, Georg Henrik von Wright, na sua obra Norm and action e posteriormente em An Essay in Deontic Logic and the General Theory of Action, idealizou um sistema lógi co que lhe permitiu relacionar as diferentes classes de prescrições normativas e propas para ele a denominação de "lógica deantica" $(\text { deontos }=\text { dever })^{121}$. Segundo Bobbio, esta lógica deantica "deveria constituir o capítulo introdutório de uma teoria geral da norma e do ordenamento jurídico"122.

Também na chamada "Escola Analítica de Buenos Aires", Alchourrón e Bulygin (Normative Systems, 1971), procuraram esclarecer as noções de sistema jurídico, suas propriedades (plenitude, coerência e independência) e seus defeitos (lacunas, incoerências e redundâncias), de conformidade com a lógica deantica ${ }^{123}$. Os autores referidos ressaltavam a estrutura dedutiva da Ciência do Direito, apesar do seu caráter empírico. Por isso "a sistematização de seus enunciados é uma das tarefas fundamentais 
de toda Ciência, tanto formal como empírica"124.

Assim, a lógica do Direito está se organizando numa Teoria Geral do Direito original, enquanto teria oferecido novos instrumentos para a superação das dificuldades que teriam bloqueado a Teoria Geral do Direito tradicional $1^{125}$

\section{c. A teoria da autopoiesis}

Uma corrente moderna da sociologia do Direito, sustenta uma teoria denominada "da autopoiesis" - Niklas Luhmann, Gunt her Teubner, Helmut Wilke - que tem revalorizado a noção de sistema. O Direito, para esta teoria, seria um subsistema da sociedade ${ }^{126}$ : "uma ordem de vida realizada na existência, que é observada constantemente pelo homem com a consciência da sua vinculabilidade". Seria um ser que teria a signifícação de um "ser devido"127.

Sempre considerando-o como subsistema social, Luhmann the atribui o carater de normativamente fechado e de cognoscitivamente aberto.

A qualidade de normativamente fechado combina-se com a de autoreferencial ${ }^{128}$. O próprio Direito fixa seus próprios limites. Portanto, pode ser tão amplo como ele pretender. Como contrapartida, não existe nada exterior ao sistema de Direito, nenhuma ordem que lhe imponha limites ${ }^{129}$.

Esta idéia fundamental, segundo a qual o Direito produz seus próprios elementos e determina sua estrutura e seus limites, não pode negar - a critério de Seve - uma forte herança kelseniana ${ }^{130}$

O sistema de Direito seria cognoscitivamente aberto enquanto suas fronteiras poderiam ser ultrapassadas. O sistema cede ante os fatos e pode automodificar-se se a pressão dos fatos se impoe. Por isso, seu caráter cognoscitivo serve à coordenação do sistema com o ambiente dentro do qual se encontra situado ${ }^{131}$.

Luhmann se refere, então, a um acoplamento estrutural, onde produzir-se-ia a rela ção entre o sistema e o mundo circundante. Por exemplo, entre o Direito e a Economia hierarquizadas, antes surgindo intermutáveis. Heterogêneo, por apresentar áreas de densidade diversa,desde coberturas integrais por proposições rígidas, até as quebras intra-sistemáticas e as lacunas rebeldes à ana$\operatorname{logia}{ }^{137}$.

Dentro de um ponto de vista metodoló gico, supoe a utilização da dedução e da indução como procedimentos complemen$\operatorname{tares}^{138}$. Ao seu lado, exige-se o recurso a critérios interpretativos novos - como a espiral hermenêutica gadameriana ${ }^{139}$-, a outra classe de conceitos - como o conceito determinado pela sua função $o^{140}$ e a outra classe de normas - como as cláusulas gerais $^{141}$.

Dentro de um ponto de vista ético, supoe a superação da racionalidade formal que Max Weber atribuia ao Direito, aproximando-o aos valores sociais, morais, religiosos e, sobretudo, ao ideal da justiça material ${ }^{142}$

Deve-se ainda dar uma resposta que al cance, se não uma adesão unânime, quando menos um certo grau de consenso na doutrina em torno de algumas questoes fundamentais. Na opinião de Joseph Raz estas questoes seriam as seguintes: quais são os critérios de existência de um sistema jurídico; quais são os critérios que determinam quando uma disposição pertence a um determinado sistema jurídico ou não; quais os padroes de relação entre as normas componentes de um sistema; e se existe um conteúdo comum a todos os sistemas jurídicos ${ }^{143}$

Estas questoes, que sem dúvida serão alvo das pesquisas futuras, são teóricas, sim. Cumprem, porém, a função que a Ciência do Direito tem tido historicamente, quando o seu objeto alcançou um ponto crítico tal que tanto a Dogmática jurídica, quanto jurisprudência dos tribunais não conseguiram vislumbrar pontos certos de referência. $\mathrm{Na}$ expressão de LOSANO, "os novos intentos metodológicos parecem, porém,encaminhar-se para uma coordenação e, no limite, para uma unificação, quando os juristas planteiam-se o problema de dar uma saída prática ao resultados puramente teóricos já adquíridos."144
Como em outros tempos, o reclamo é por uma modernização do Direito que não descuide a certeza jurídica. Existem, também, novas exigências, desde o âmbito da informática, que precisam de uma exposição formal que forneça ao Direito uma lógica externa e padroes uniformes, com a finalidade de controlar a correção dos procedimentos demonstrativos no âmbito do Direito. Daí deriva-se uma formalização que pode confiar-se ao ordenador eletranico, o qual desenvolveria as operações de controle lógico sobre as normas,quantas vezes fosse necessário. Assim, geram-se duas grandes vias à utilização do ordenador eletranico no Direito: por um lado, com seu uso na pesquisa documental, inicia-se a história de informática jurídica; por um outro lado, com os primeiros intentos de aplicar normas jurídicas aos casos concretos mediante o ordenador, abre-se a história de modelística, destinada a ter um reflexo sobre a atividade legislativa ${ }^{145}$.

Finalmente, existem razoes de estratégia regional para os nossos países, que pretendem, num futuro próximo, alcançar a harmonização das suas legislações.

\section{Bibliografia}

Alchourrón, Carlos \& Bulygin, Eugenio. Introducción a la metodología de las ciencias jurídicas y sociales. Trad. dos autores. Título original: "Normative Systems" (1971). Primeira reimpressão em castelhano. Buenos Aires: Astra, 1987

Bello, Andrés. El Araucano (1833). In: El pensamiento vivo de Andrés Bello. Presentación de Germán Arciniegas. Buenos Aires: Losada, 1946.

Bobbio, Norberto. Teoria dell'Ordinamento Giuridico. Torino: G. Giappichelli, 1960.

Bodenheimer, Edgar. Teoría del Derecho. 2 ed. México: Fondo de Cultura Económica, 1964 (1 ed. em inglês 1940).

- . Ciência do Direito, Filosofia e Metodologia Jurídicas. Trad. por Enéas Marzano. Rio de Janeiro: Forense, 1966. Versão intitulada "Jurisprudence, the Philosophy and the Law", Harvard University Press, Cam-

bridge, Massachusetts, 1962. intensivo por se compatibilizar, no seu interior, com elementos materiais a ele estranhos. Móvel, por não postular proposições
Bonfante, Pietro. Historia del Derecho Romano. Madrid: Revista de Derecho Privado, 1944. v.1-2. 
Canaris, Claus-Wilhelm. Pensamento Sistemático e Conceito de Sistema na Ciência do Direito. "Systemdenken und Sistembegriff in der Jurisprudenz" /1983). Lisboa: Fundação Calouste Gulbenkian, 1989. Intr. trad. de Antonio Manuel Menezes Cordeiro. Origińal alemão.

Castro Rivera, Alicia. El problema metodológico en la Ciencia del Derecho. Revista de la Facultad de Derecho y Ciencias Sociales, Montevideo. v.30, n.1-2, p.179, jan./jun., 1989.

Carvalho, Orlando. Teixeira de Freitas e a unificação do Direito Privado, Coimbra. Boletim da Faculdade de Direito da Universidade de Coimbra, v.60 , p.1, 1984.

Cassirer, Ernst. The Philosophy of Enlightenment. Trad. por Fritz C.A. Koelln \& James P. Pettergrove. Título original: Die Philosophie der Aufklarung (1932). Boston: Beacon Press, $1961.366 \mathrm{p}$.

Coing, Helmut. Historia y Significado de la Idea de Sistema en la Jurisprudencia. México: Centro de Estudios de la Universidad Nacional Autónoma, 1959.

- - Fundamentos de Filosofia del Derecho. Trad. por Juan Manuel Mauri. Barcelona: Ariel, 1961.

- . An intellectual history of european codification in the eighteenth and nineteenth centuries, in: Research School of Social Sciences (Department of Law), Australian National University, Problems of Codification. Camberra: S. J. Stol- jar, 1977. p.16-33.

Combacau, Jean. Le Droit International: bric-à-brac où système?. Archives de Philosophie du Droit: le Système Juridique, Paris, v.3l, 1986.

Costa, Judith Martins. As cláusulas gerais como fatores de mo- bilidade do sistema jurídico. Revista de Informaşão Legis- lativa. v.28, n.112, out./dez., 1991.

David; René \& Jauffret Spinossi, Camile. Les Grands Systemes de Droit Contemporaines. 9.ed. Paris: Dalloz, 1988.

De Los Mozos, José Luis. Derecho Civil: Método, Sistemas y Categorías Jurídicas. Madrid: Civitas, 1988.

De Cupis, Adriano. Commenti. Rivista di Diritto Italiano, V.1, 1979.

Engisch, Karl. Introduşão ao pensamento jurídico Trad. por J. Baptista Machado. 3.ed. Lisboa: Fundação Calouste Gulbenkian, 1977.

Esser, Josef. Principio y Norma en la Elaboración Jurispruden- cial del Derecho Privado. Trad. por Eduardo Valenti Fiol. Barcelona: Bosch, 1961.

Ferraz Junior, Tercio Sampaio. Conceito de Sistema no Direito: Uma Investigação Histórica a partir de Obra Filosófica de Emil Lask. São Paulo: Rev. dos Tribunais.

Gaudemet, Jean. Tentatives de Systèmatisation du Droit à. Rome. Archives de Philosophie du Droit: le Système Juridique. v.3l, 1986.
Gomes, Orlando. A caminho dos micros-sistemas. In Estudos jurídicos em homenagem ao prof. Caio Mário da Silva Pereira. Rio de Janeiro: Forense, 1984.

Heymann, Ezra. La hermenéutica: De teoría de la in terpretación a concepción de la filosofia. Relaciones. n.80/81, jan./feb. 1991, p.9/10.

Henkin, Leon. Completude. In:Filosofia da ciência. Trad. de Leonidas Hegenberg e Octany Siveira da Mota. Título do original: Philosophy of Sciences Series (Forum Lextures). 3.ed. São Paulo: Cultrix, 1979.

rti, Natalino. Leggi Speciali. Rivista di Diritto Civile Italiano, v.2, 1979.

- . L'età della decodificazione. Milano: Giuffrè, 1989. 3a ed.

James, William. Pragmatismo: un nombre nuevo para viejos modos de pensar. Buenos Aires: Emecé, 1945. Trad. do inglês por Vicente P. Quintero. Nota preliminar por Jorge Luis Borges. Título original: Prag matism: A New Name for Some Old Ways of Thinking. 1.ed. em 1907.

Koschaker, Paul. Europa y el Derecho Romano. Trad. do alemão por José Santa Cruz Teijeiro. Madrid: Revis ta de Derecho Privado, 1955.

Larenz, Karl. Metodología de la Ciencia del Derecho. Bar celona: Ariel, 1966. Trad. da 1.ed. (1960) por E Gimbernat Ordeig.

- . Metodologia da Ciência do Direito. Trad. por José Lamego. 2.ed. Lisboa: Fundação Calouste Gulbenkian, 1989. Titulo Original: Methodenlehre der Rechtswissenschaft (1983).

Losano, Mario G. Sistema e struttura nel Diritto. Torino: Giappichelli, 1968.

- - Curso de informática jurídica. Título original: Corso di informatica giuridica, v.1. Madrid: Tecnos, 1987. $262 \mathrm{p}$

Luhmann, Niklas. L'unité du système juridique. Archive de Philosophie du Droit: le système juridique, V.31, 1986.

- . Sistema giuridico e dogmatica giuridica. Bologn Mulino, 1978.

Marques, Mario Reis. O liberalismo e a Codificação do Direito Civil em Portugal. Boletim da Faculdade de Direito da Uni-versidade de Coimbra. V.29. 1986.

Mendonca, Daniel. Noorma, lógica y sistema. Buenos Aires, 1970.

Motilla, Agustin. La Codificación como Técnica Legislativa. Revista de Derecho Privado, Madrid, p.545-574, jun. 1987.

Pascual Quintana, Juan Manuel. La encrucijada del Derecho Civil, Estudios en honor al Prof. Castán Tobe ñas. v.1.

Pereira, Caio Mario da Silva. Instituigôes de Direito Civil. 9.ed. Rio de Janeiro: Forense, 1985. v.1.
Radbruch, Gustav. Introducción a la Filosofia del Derecho. México: Fondo de Cultura Económica, 1951.

Raz, Joseph. Il Concetto de Sistema Giuridico. Trad. por Paolo Comanducciti. Bologna: Il Molino, 1977. Ed. original: "The Concepto of a Legal System. An Introduction to the Theory of Legal System", 1970.

Reale, Miguel. Filosofia do Direito. 2. ed. São Paulo: Saraiva, 1957.

Rovaletti, Lucrecia. Teoría general de los sistemas. $R$ laciones. n.29, 1986, p.12-14.

Sacco, Rodolfo. Codificare: un modo superato di legificare?. Rivista di Diritto Civile Italiano. v.29, n.2. 1983.

Seve, René. Introducción al t.31. Archives de Philosophie $d u$ Droit: le système juridique, Paris, v.31, 1986.

- Système et Code. Archives de Pbilosophie du Droit: le système juridique, Paris, v.31, 1986.

Silva, Clóvis V. do Couto. O Direito Civil Brasileiro em Perspectiva Histórica e Visão de Futuro. AJURIS, v 40 jul 1987. Conferência realizada na Faculdad ve Dir.

Solari, Gioele. Filosofia del Derecho Privado. Trad. Oberdan Caletti. Buenos Aires: Depalma 1946. Original italiano: Individualismo e Diritto Privado, 1939.

Thibaut \& Savigny. La Polemica sulla Codificazione. $\mathrm{Na}$ poli: Ed. Scientifica Italiana, 1982.

Vadallao, Haroldo. O Código Civil Brasileiro e sua reforma. Estrutura e Sistemática. Códigos Multiplicados, Especiais e Autanomos. Revista do Curso D reito Universidade Federal de Uberlandia. v.7, n.1, 1978

Varela, João de Matos Antunes. O Movimento de descodificação do Direito Civil. In: Estudos Jurídicos em Homenuarm ao Professor Caio Mario da Silva Pereira. Rio de Janeiro: Forense, 1984. p.499.

Varga, Csaba. Utopias of rationality in the develop ment of the idea of codification. Rivista Internazionale di Filosofia del Diritto. v.55 (4a. Série), 1978, p.21.

Vaz Ferreira, Carlos. Lógica viva. Estudo preliminar por Jorge Liberati. Texto ao cuidado de Sara Vaz Ferreira. Montevideo: Técnica, 1983. Ed. original em 1910.

Viehweg, Theodor. Tópica y jurisprudencia. Trad. po Luis Diez Picazo Ponce de León. Madrid: Taurus, 1964. Título original: Topik und Jurisprudenz, 1952.

Warat, Luis Alberto. $O$ direito e sua linguagem. Com colaboração de Leonel Severo Rocha e Gisele Guimaraes Cittadino. 2a versão. Porto Alegre: Fabris, 1984. $103 \mathrm{pp}$

Wieacker, Franz. História do Direito Privado Moderno. Trad. por A. M. Botelho Hespanha. Lisboa: Fundação Calouste Gulbenkian, 1980.

Resume o próprio Losano: "... la prima parte della ricerca si limita ad elencare e ad analizzare i successivi
significati che il termine 'sistema' è andato assumendo significati che il termine sistema etesi nella filosofia dalle origini greche fino all'apoteosi nella filosofia classica tedesca ed alle dure critiche degli illuministi
francesi..." (página XXI) "... L'esame della storia semantica di 'sistema' giunge fino all Ottocento é l'epoca della Scuola storica del diritto. Essa elaboro una noione di sistema giuridico che è ancor oggi largamente diffusa tra i giuristi ..." (p.XXIII).

2 IRTI, Natalino, L'etá della decodificazione, p.181.

${ }^{3}$ Losano, Mario G., Sistema e Struttura nel Diritto, v.1, Dalle Origni alla Sculh Storice, PIX. "Infatti, ogetto di sistema izaione pú essere tanto la realth quanto dis sistematizzazione puó essere tanto la realta, quanto Thrieme di proposizon essere tan si laschive la realta. nel secondo di sistemi ideali.".

${ }^{4}$ Id. ibid., p.XXV/XXVI

${ }^{5}$ Kant, Savigny, Binder e Coing, apud Canaris, ClausWilhelm Pensamento Sistemático e Conceito de Sistema na Ciência do Direito, p.10/11.

6 Canaris, Claus-Wilhelm, op. cit., p.13.

7 Carvalho, Neto de, Direito, Biologia e Sociedades, p.21/22; Cordeiro, Antonio Manuel da Rocha e Menezes, in: Canaris, Pensamento Sistemático e Conceito Sistema na Ciência do Direito, Introdução, cap.III.

${ }^{8}$ De fato, a história do Direito Romano mostra somente duas leis com vocação compreensiva: a Lei das XII Tábuas e o Corpus Iuris de Justiniano. No largo intervalo entre estas duas leis, não há nenhuma outra codificação. (Radbruch, Gustav, Introducción a la Filosofia del Derecho, p.66; Coing, Helmut, Historia y Significado de la Idea de Sistema en la Jurisprudencia, 25/26: Bonfante, Pietro, Historia del Derecho Romano, v.1, p.151 e v.2, p.77.

9 A origem da palavra codex e caudex, que significa "tronco de árvore". Aludia-se, com dita expressão, à madeira que servia como material de escrita. Mais tarde, e apesar de que no século III dC, o uso do pergaminho tenha-se imposto no lugar da madeira, a palavra codex continua a significar livro. Ao serem publicadas em forma de codex as constituições do Baixo Império - Codex Gregorianus, Hermogenianus, Theodosianus e, posteriormente, Codex Justinianus -, a expressão em análise estendeu-se definitivamente no âmbito juridico. (Motilla, Agustín, La codificación como técnica legislativa, Revista de Derecho Privado, jun. 1987, p.545/546).

10 Coing, Helmut, op. cit., p.27, \& Gaudemet, Jean, Tentatives de systematisation du droit à Rome, Archive de Philosophie du Droit, v.31, p.26: "Curieusement l'énorme travail qu'opérent les commisaires de Justinien dans les anées $520 / 530$ ne fut marqué par aucun progrés dans la systématisation du droit romain. C'est que leur oeuvre fut essentiellement de choix dans la masse 
documentaire du passé, et de mise à jour de textes. Le travail fut de compilation, non de création". Também Valladao, Haroldo: O Código Civil brasileiro e sua reforma. Estrutura e sistemática. Códigos multiplica-
dos, especiais e autanomos, Revista do curso de Direito dos, especiais e autanomos, Revista do curso de Direito
da,Universidade Federal de Uberlandia, v.7, n.1, p.16.

11 Cordeiro, Antanio Manuel da Rocha e Menezes, in: Canaris, Pensamento Sistemático e Conceito de Sistema na Ciência do Direito, Introdução, p.LXXI.

12 Valladao, op. cit., p.16/17.

${ }^{13}$ Ao Codex Statutorum segue a obra francesa Code de Henri III e, no século XVII o Code de Henri IV (Motilla, Agustín, La codificación como técnica legislativa, Revista de Derecho Privado, 1987, p.546).

14 Coing, op. cit., p.31.

15 Por contraposiçào à metodologia clássica (newtoni na), que concebia o objeto da investigação científica como uma coleção de componentes isolados, de cujas propriedades tentava deduzir as propriedades de todos os objetos sem ter em conta a interação entre as partes (Rovaletti, Lucrecia, Teoría general de los sistemas, Relaciones, n.29, 1986, p. 12)

16 Rovaletti, porém, considera que a visão sistêmica da realidade foi substituída por René Descartes, fundamentalmente na segunda regra do Discours do la Máthode que requer a fragmentacào de todo problema em $a c$, que rementos simples e separados quaboblema em sível (Teoría general de los sistemas, Relaciones, n.29, p.12).

17 Cordeiro, in: Canaris, Pensamento Sistemático e Conceito de Sistema na Ciência do Direito, Introdução, p.LXXVII.

18 "Recorde-se que o trabalbo de Euclides, na Geometria, considerado como o protótipo das teorias axiomáticas, principia com definicỗes dos termos (como ponto e reta) que surgem nos axiomas e introduz, posteriormente, os termos (como linha reta e círculo) que surgem na formulaşãa dos teoremas." Henkin, Leon, Completude, in: Filosafin da Ciência, p.68/69.

19 Canaris, op. cit., p.38.

20 Koschaker, Paul. Europa y el Derecho Romano, p.355/356.

21 Cassirer, Ernst. The Pbilosophy of the Enlightenment, p.237.

22 Ibid., p.356/357.

$23 \mathrm{O}$ Postulado da Evidência implica que em toda a Ciência deve existir um número finito de enunciados tais que a verdade deles seja tão óbvia, que não necessite prova alguma e que a verdade de todos os demais enunciados pertencentes a essa Ciência deva poder estabelecer-se por meio da inferência lógica, a partir daqueles enunciados.

O Postulado da Dedução sustenta que se determinados enuncia- dos pertencem a uma Ciência toda conse qüência lógica desses enunciados deve pertencer a essa Ciência.
Alchourrón, Carlos \& Bulygin, Eugenio, Introducción a a Metodología de las Ciencias Jurídicas y Sociales. p.82. ${ }^{24}$ Cordeiro, op. cit., p.LXXX.

25 Koschaker, op. cit., p.359/360.

${ }^{26}$ Alchourrón \& Bulygin, op. cit., p. 90.

27 Castro Rivera, Alicia. El Problema Metodológico en la Ciencia del Derecho, Revista de la Facultad de Derecho y Ciencias Sociales de Montevideo, 1989, p.188.

28 Alchourrón \& Bulygin, op. cit., p.90. Castro Rivera, op. cit., p. 188

${ }^{29}$ Losano, op. cit., p.115 e ss.

${ }^{30}$ Engisch, Introdusãa ao Pensamento Jurídico, p.253.

31 Bobbio, Norberto, Teoria dell'ordinamento giuridico, p 80 - 82. "... si dice che un ordinamento giuridico Possono coesister valí del principio che esclude la incompatilità delle varí tutte debbono

32 Por isso, o art. 4 do Código Civil francês dispas: Le juge qui refusera de juger sous prètexte du silence de lobscurite ou de l'insuffisance de la loi pourra ètre poursuivi comme culpable de dèni de justice" (apud $\mathrm{K}$. Engisch, Intro- dusáa ao pensamento jurídico, p.215).

${ }^{33}$ Larenz, Metodologia da Ciência do Direito, p.532/533. Esser, Josef, Principio y Norma en la Elaboración Jurisprudencial del Derecho Privado, p.532.

${ }^{34}$ Alchourrón \& Bulygin, op. cit., p.42.

${ }^{35}$ Larenz, Metodologia da Ciência do Direito, p.19.

36 Ibid., p.20

${ }^{37}$ Ibid., p.20/21.

38 Koschaker, op. cit., p. 365 .

39 Larenz, Metodologia da Ciência do Direito, p.12.

40 Ibid., p.20.

41 Wieacker, Franz, História do Direito Privado Moder $n o$, p.445-447.

42 Apud Irti, Natalino, L'etá della decodificazione, p.166.

${ }^{43}$ Koschaker, p. 370 .

44 Ibid., p. $369 / 370$.

45. Larenz, Metodologia da Ciência do Direito, p.21/22.

46 Wieacker, op. cit., p.457.

${ }^{47}$ Larenz, op. cit., p.23-26

48 Varela, João de Matos Antunes, O movimento de descodifi- cação do Direito Civil, Estudos jurídicos em Homenagem ao Prof. Caio Mario da Silva Pereira, p.501/502.

No mesmo sentido De Los Mozos, Derecho Civil (Me Sistemas y Caterories juridicash p.97. ". resulda

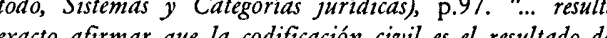
doble imputso romenisa y racionalist conversultado ad consiltera atribuciones y probibiciones), que señalan la conducta justa observar, directamente o mediante el razonamiento y la deducción lógica".

49 O termo "codificação" parece ter sido criado por Bentham. Cf. COING, An intellectual history of euro(a) eighteenth and nineteenth pean codification ins of codifications, p.16.

50 Valladao, op. cit., p.17-18.

51 Varga, Csaba. Utopias of rationality in the development of the idea of codification, Rivista Internationale di Filoso- fia del Diritto, 1978, p.22: "... the Prussian Allgemeines Landrecht grew out of patriarchal despotism yielding special features to local Prussian absolutism and also ensued from Frederick's obsession to have a hand in every-thing".

52 De Los Mozos, op. cit., p.105; Cordeiro, op. cit., p.LXXXVI.

Para uma ampliação dos precedentes, fontes e fundamentos do Código prussiano e austríaco, ver Sola

Gioele: Filosofia

53 Id. ibid., p.106.

54 Ibid., p.107.

55 Gomes, Orlando, $A$ caminho dos micro-sistemas, p.160 56 Values, $O$ movimento de descodificasăa do Direito Civil, p.502.

57 Cordeiro, op. cit., p.LXXXVI.

58 Solari, op. cit., p.ll8 ss.

59 Conceito mencionado por Luhmann em L'unité du

juridique, v.31, Archives de Pbilosophie du systeme
Droit.

60 Koschaker, op. cit., p. 370 .

De Los Mozos, op. cit., p.97: "Fundado el código en un conjunto reducido de principios generales, de lo que derivan más específicos, con él se entiende poder resolver todas las cuestiones imaginables, ahora y en adelante".

Esser, J., Principio y Norma en la Elaboración Jurispr dencial del Derecho Privado, p.184, considera o Código Napoleanico como representante de "un pensamien axiomático totalmente unitario, que se caracteriza por devaluar e ignorar los principios valorativos abiertos. . En lugar de ellos pone en primer plano las rationes legis, los princi- pios formales de la estructura y de la lógica jurídica ...".

61 Cf a distinção efetuada por Esser entre sistema externo e sistema interno.

62 Cordeiro, op. cit., p.LXXXVI.

63 IRTI, Natalino, Leggi speciali, Rivista di Diritto Civile Italiano, 1979, p.141/142.

64 De Los Mozos, op. cit., p.136.

65 Ibid., p.136/137. Vadallao, p.19/20. Vinte anos antes da aprovação do Código Civil chileno, Andrés Bello justificava da seguinte forma a necessidade de codificar - Direito Privado: "Pocos necesitarán que se les demuestre la necesidad de codificar nuestras leyes.. Sin aquel paso preliminar, ni es posible que las leyes tan generalmente conocidas, como deben serlo sean tan generalmente conta la conducta de los para que dirijan eficazmente la conducta de los hombres, ni pueden dejar de convertire ficus un medios de opresión contra los débiles, y en lazos y trampas, que la codicia y el fraude arman a los inca tos. Sin aquel paso previo, el laberinto de una legislción como la nuestra hará siempre ilusorias e insignficantes las garantias constitucionales, habra siempre incertidumbre y vacilación en los jueces, arbitrariedad inconsecuencia en los juicios". El Araucano, 1833, transcrito no Pensamento Vivo de Andrés Bello, apresenado permán Arciniegas. Buenos Aires, Losada, 1946.

66 De Los Mozos, op. cit., p.lll ss.

Wieacker, p.401: "Na verdade, também na Alemanha, sobretudo depois da legislą̧áa napoleanica uma pane da

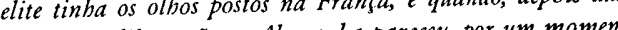
guerras da libertasaso, a Alemanha pareceu, por um momento, estar pronta para uma democracia nacional unificad esta elite pensou que o caminbo estava livre para uma Constituigão comum a toda a Alemanba e para um Codlo Geral que fosse, não decretado, mas elaborado por toda a naşão. Mas o que passou foi que estas forgas foram imediatamente subjugadas pela restauraşão dos Estados territoriais e forşadas ao "caminbo interno" de uma renovaşão do e Jireito a partir de uma conciência jurídica bistórica e cientifica,...".

Ver também do mesmo autor as p.445 ss.

${ }^{67}$ Koschaker, op. cit., p. 413

68 De Los Mozos, op. cit., p.l15 ss.

${ }^{69}$ Cordeiro, op. cit., p.XCVI: "Como qualquer co dificaso o B.G B traduz uma recolba do já existente e não uma Giasio de novidades sintetiza a Ciência Jurílica do século $X I X$ no que ela tinba de mais evoluido".

${ }^{70}$ Radbruch, Introducción a la Filosofia del Derecho, p.77 ss. Wieacker, op. cit., p.549/551.

71 Apud Gomes, op. cit., p.161.

72 Varela, Antunes, op. cit., p. 502.

De Los Mozos, op. cit., p.l19.

Wieacker, op. cit., p.457.

${ }^{3}$ Gomes, op. cit., p.162.

Radbruch, op. cit., p.78/79.

$\mathrm{Na}$ opinião de Esser (p.282), a sistematização axioma tica do Direito Privado Alemão, "no consiguió desterrar antiguas pretensiones de la judicatura de trabajar directa mente sobre los problemas tal como bacía antes de la codif. cación. Aquí codificación no significa revolución. Esto se

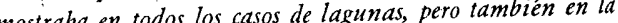
afanosa aceptación de los poderes conferidos por las normas a

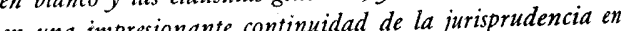
an una 74 Koschaker, op. cit., p. 413.

75 De Los Mozos, op. cit., p.ll8.

David, René \& Jauffret-Spinosi, Camille, Les Grands Systemes de Droit Contemporains, p. 95 . 
76 David \& Jauffret-Spinosi, op.cit., p.95: "La pertic générale du BGB est issue de l'enseignement très dogmatique donnè dans les Universites allemandes par l'Ecole des Pandectistes, qui a profondément renouvelé, en prétendant le systématiser, le 'jus commune' apliqué en Allemagne au Xe. siecle".

A introdução de uma "parte geral" em um texto de Direito Positivo, tem recebido algumas criticas. Wieacker, por exemplo, a considera "dispensavel, quando não prejudicial" (p. 560)

77 Silva, Clóvis Veríssimo do Couto e. O Direito Civil Brasileiro em Perspectiva Histórica e Visão do Futuro. Ajuris n.40, p.128 ss.

Advertem David e Jauffret-Spinosi, que a idéia de uma "parte geral" estava presente como forma legislativa pela primeira vez no Brasil, na "Consolidação das leis civis" elaborada por Augusto Teixeira de Freitas (1858). O Código Civil brasileiro de 1916 incorporou em seu texto uma "parte geral", talvez mais em razão do dito precedente, que por imitação do B.G.B.

78 Cordeiro, op. cit., p. XCVIII.

79 Henkin, Leon, Completude, in:Filosofia da Ciência, p.69.

80 Ibid., p.74.

81 James, William, Pragmatismo: un nombre nuevo para algunos viejos modos de pensar, p.120.

82 Vaz Ferreira, Carlos Lógica Viva, p.114. Este tipo de consideração se segue repetindo ainda hoje. Por exemplo, Seve, na sua introduçào ao v.XXXI, dos Archives de Philosophie du Droit, p.6: "On ne s"etonnera pas de voir la notion de systeme appliquée au droit puisque l'esprit ne peut comprendre un objet complexe que sous la catégorie de la systématicité...".

83 Op. cit., p. 124

84 Wieacker, op. cit., p.646/647.

85 Ibid., p.645 ss "As modalidades desta concep̧ão mais ricas em conseqüencias são o naturalismo mecanicista, que interpreta as concepsöes jurídicas a maneira de processos origi nados por causas e influências externas... o vitalista, que interpreta o direito como uma funşão da vida biológica, nos moldes das ciências biológicas; e o psicológico, que o domínio da psicologia individual on da psicologia coletivo

${ }^{86}$ Ibid., p.662-669.

87 Wieacker, op. cit., p.670/671.

88 Ibid., p.665.

Bondenheimer, op. cit., p.172.

${ }^{89}$ Der Kampf um die Rechtswissenschaft, citado no epígrafe da suá obra por Alchourrón \& Bulygin.

${ }^{90}$ Larenz, Metodologia da Ciência do Direito, p.56/57.

91 Ibid., p.59.

92 Cordeiro, Introdução, in: Canaris, Pensamento Sistemático e Conceito de Sistema na Ciéncia do Direito, p.LXVII.

${ }^{93}$ Larenz, op. cit., p.65.
94 Ibid., p.66/67.

95 Canaris, Pensamento Sistemático e Conceito de Sistema na Ciência do Direito, p.55 ss.

${ }^{96}$ Canaris, op. cit.

97 Wieacker, op. cit., p.668/669.

98 Bodenheimer, op. cit., p.91.

${ }^{99}$ Alchourrón \& Bulygin, op. cit., p.91.

100 Wieacker, op. cit., p.669.

${ }^{101}$ Achourron \& Bulygin, op. cit., p.91.

102 Apud Bodenheimer, op. cit., p.172.

103 Wieacker, op. cit., p.28

Pascual Quintana, Juan Manuel, La Encrucijada del Derecho Civil, Estudios en Honor del Profesor Castán Tobeñas. I. p.419 ss.

Irti, Natalino, Leggi Speciali, p. 142/143.

104 Varela, Antunes, op. cit., p.504

105 Ibid., p.505.

106 Valladao, op. cit. p.22.

107 Raiser, Ludwig, O Futuro do Direito Privado, $R$ vista da Procuradoria Geral do Estado, n.25, p.13.

${ }^{108}$ Sacco, Rodolfo, Codificare modo superato di legificare, p.ll8.

109 Irti, op. cit., p.143/144

110 Ibid., op. cit., p.145.

De Cupis, Adriano, Commenti - Revista de Derecbo Civil Italiano, 1979. v.l. p.5l - objeta esta afirmáãa de Irti

111 Pereira, Caio Mário da Silva, Institusões de Direito Civil, p.64-66.

Cabe recordar que já em 1866, Teixeira de Freitas considerava necessário fazer um Código Geral, dominand a legislação inteira, com definições, regras sobre publcação, interpretação e aplicação das leis. Valladao, Código Civil brasileiro e sua reforma, Revista do Curso Direito da Universidade Federal de Uberlandia, v.7, n.1 p.20.

112 Costa, Judith Martins. As cláusulas gerais como fatores de mobilidade do sistema jurídico, Revista de Informafão Legislativa, n.112, p.28.

113 Silva, Clóvis Veríssimo do Couto e. O Direito civil brasileiro em perspectiva histórica e visão de futuro, Ajuris n.40, p.148.

114 Viehweg, Tópica Y Jurisprudencia, cap. VII.

115 Ibid., p.127.

116 Ibid., cap. III.

117 Id. ibid.

118 Id. ibid.

119 Losano, Curso de informática juridica, p.28.

${ }^{120}$ Alchourrón \& Bulygin, op. cit., p.91.

${ }^{121}$ Mendonca, Daniel, Norma, Lógica e Sistema, p.25 ss.

122 Apud Losano, Curso..., p.29.

123 Mendonca, op. cit., p.51.
124 Canaris, op. cit., p.35-38.

125 Losano, op. cit., p.28.

126 Luhmann, Niklas, L'unité du système juridique, Archives de Philosophie du Droit, v.XXXI, Le Système Juridique, p.172.

${ }^{127}$ Larenz, Metodologia de la Ciencia del Derecho, tradução ao espanhol da primeira edição, p.159.

128 Luhmann considera como auto-referencial, aquele sistem que produz, por si mesmo, enquanto que unisistema que produs, por si mo unidade (op. cit., p.165). 129 Luhmann, em conferência sobre o tema "A criação jurídica e a teoria dos sistemas", proferida em 5 de setembro de 1990 na Faculdade de Dite da sidade Federal de Rio Grande do Sul (Porto Alegre).
${ }^{130}$ Seve, Introduction, Archives de Philosophie de Droit, v. XXXI, p.9.

131 Luhmann, op. cit., p.173.

132 Luhmann, conferência citada.

133 Id: ibid.

134 Larenz, Metodologia da Ciência do Direito, p.533.

135 Canaris, Pensamento Sistemático e Conceito de Sistema na Ciência do Direito, p.66 ss.

136 Ibid., p.18 ss.

137 Cordeiro, op. cit., p.CXII

138 Esser, Josef, Principio y Norma en la Elaboración

Jurisprudencial del Derecho Privado, p.61.

139 Larenz, op. cit., p.242.

Heymann, Ezra. La hermenéutica. de teoria de la interpretación a concepción de la filosofia. Relaciones. n.80/81, p.9/10.

140 Larenz, op. cit., p.586.

141 "Por esta via, idéias genéricas e albeadas de uma elaboraşão acabada e casuistica - como as de boa-fe, bons cost mes, uso abusivo de direito, usos do trafico juridico e outras similares, que só produzem frutos quando animadas por problemas reais, passam a funcionar como pontos de partida para a formasáo concreta de normas jurrdicas. "Martins Costa, Judith, As clausulas gerais como fatores de mobilidade do sistema juridico, Revista Legislativa, n.112, p.21)

142 Seve, René, op. cit., p.9.

143 Apud Mendonca, Daniel, Norma, Lógica y Sistema, p.51/52.

144 Losano, Curso..., p.30.

145 Outras importantes correntes metodológicas contribuem para a investigação sobre a aplicaçăo dos ordenadores eletranicos no Direito, por exemplo o análisis linguístico do Direito e o estruturalismo. Losano, op. cit., p.31.

Warat, Luis Alberto. $O$ direito e sua linguagem. 